\title{
Hubungan antara Ketaatan Beragama dengan Kinerja Bisnis Pengusaha di Banjarmasin
}

\author{
Abdurrahman Sadikin \\ FEB Universitas Lambung Mangkurat Banjarmasin \\ Satira Yusuf \\ FEB Universitas Halu Oleo Kendari \\ abdurrahman sadikin79@yahoo.co.id
}

\begin{abstract}
The purpose of this study is to identify the correlation between religious observance factors (Islam) consist of ritual worship, fiqh muammalah, social piety and management of working culture to business performance of Muslim businessman in Banjarmasin. Samples were taken using simple random sampling method, in this case executor equipped survey sample frame in the form of a list of most of the Muslim businessmen in accordance with criteria. For the preparation of the sample frame there are various approaches that can be done, among others, by seeing the large volume of business, type of business, the business scope and so on. The results showed that: There was a significant correlation between the variables of religious observance with business performance of Muslim businessman. The strongest correlation is shown by the variable jurisprudence muamalah with business performance, are $0.388 \%$. A Muslim businessman constantly strive to actualize himself, to serve (antum a'lamu bi umiri dunyakum), serving consumers or people who put him or her expectations (consumer), as well as providing good service to people or institutions who seek to help or promote himself and his business. But all that, he did with full awareness as devotion to the Most Specifies for all, Allah. As a very famous statement in the world of Sufism, "Ilaahi anta maqshudi wa ridhaaka mathluubi."
\end{abstract}

Keywords: Religious observance, management of working culture, and muslim businessmen

\section{LATAR BELAKANG}

Siklus kehidupan ekonomi telah menyebabkan naik-turun atau maju-mundurnya perkembangan dunia bisnis menjadi sebuah 
hal yang biasa. Krisis moneter yang meluas pada krisis multidimensional di tahun 1997 lalu merupakan gambaran yang sangat gamblang bagaimana suatu kemunduran ekonomi telah berdampak pada semua sektor didalamnya. Krisis ini sempat menjatuhkan pertumbuhan ekonomi pada tingkat minus atau dibawah nol persen. Hal ini terjadi meski beberapa tahun sebelum masa tersebut perekonomian Indonesia seakan berada pada masa booming dimana pertumbuhan rata-rata selalu berada di atas $7 \%$ pertahun. Dunia usaha terlena menikmati musim semi sebelum akhirnya jatuh dalam keterpurukan.

Meski demikian, kondisi yang dinamis tersebut tidak harus menyebabkan dunia usaha mati untuk selamanya. Terbukti bahwa disamping sejumlah pengusaha yang tamat riwayatnya, banyak pula unit usaha yang mampu bangkit setelah keterpurukan dan kemudian eksis secara berkesinambungan.

Di Banjarmasin sendiri dalam beberapa dekade terakhir terdapat perkembangan yang sangat khas untuk di pelajari. Sejak tahun 1970-an bisnis yang signifikan, yakni perdagangan, telah didominasi oleh warga keturunan Tionghoa. Akan tetapi pedagang pribumi / muslim yang menjual bahan-bahan sandang, pangan, dan beberapa alat-alat permesinan masih dapat mengimbangi dan dirasakan peranannya. Setelah sekian waktu berjalan kelompok terakhir ini makin termarginalkan oleh zaman (Siregar,1998). Hingga kondisi terakhir kini, meski belum pernah terungkap data pastinya, diyakini bahwa nilai kepemilikan asset bisnis perdagangan dikawasan terkemuka di Banjarmasin yang dimiliki pengusaha muslim tidak lebih dari $30 \%$.

Disisi lain terungkap kenyataan justru unit kegiatan produktif yang tangguh dan langgeng meski diterpa krisis adalah sektor usaha kecil dan menengah yang lekat dengan prinsip pergerakan ekonomi Islam, disisi lainpun Lembaga keuangan mikro berbasis syari'ah juga terbukti mampu membuktikan diri sebagai paling sehat dibanding yang berbasis konvensional.

Dalam konsepnya, Islam tidak pernah memisahkan ekonomi dengan akhlaq. Hal tersebut yang membedakan Islam dengan kapitalisme dan materialisme. Islam juga tidak pernah memisahkan ilmu dengan akhlaq, politik dengan akhlaq, perang dengan akhlaq dan aktivitas mu'amalah lainnya dengan akhlaq (Anonim, 2000). Akhlaq dalam konsep Islam mungkin sepadan dengan konsep moral dalam pandangan umum. Kenyataannya 
moral memang bersifat universal. Pembeli akan merasa kecewa jika tertipu atau majikan akan merasa sakit hati jika pekerja malas bekerja dan sebagainya. Secara universal, siapapun tidak akan senang jika diperlakukan secara a-moral.

Nabi SAW bersabda, "Sesunggulnya aku diutus untuk menyempumakan akhlak mulia". Risalah yang dibawa beliau merupakan sekumpulan/set peraturan berupa perintah dan larangan untuk membina umat menjadi yang terbaik. Oleh karenanya akhlaq merupakan pengejawantahan dari tingkat ketaatan seorang muslim terhadap nilai-nilai agamanya. Beranjak dari latar belakang tersebut maka masalah yang akan diangkat dalam penelitian ini adalah apakah faktor-faktor ketaatan beragama (Islam): ibadah ritual, fiqh muammalah, kesalehan sosial dan Manajemen Budaya Kerja berkorelasi signifikan terhadap kinerja bisnis pengusaha di Banjarmasin?.

\section{TINJAUAN PUSTAKA}

1. Ketaatan Beragama dalam Islam

Dalam perbincangan tentang akhlaq, seringkali kita mendengar beberapa kalangan membagi ajaran Islam ke dalam tiga bagian yaitu: (1) aqidah, (2) syari'ah dan (3) akhlaq. Namun sebagian lagi membagi Islam ke dalam dua bagian besar yaitu (1) aqidah dan (2) syari'ah, atau dengan kata lain (1) aqidah dan (2) nizam. (Syaltut, 2001).

Bagaimana sebenarnya kedudukan akhlaq dalam Islam? Islam mengatur dan menempatkan akhlaq sebagai bagian dari hukum syara' yang mengatur hubungan manusia dengan dirinya, melalui hukum-hukum syari'at yang berkaitan dengan sifat-sifat akhlak. Akhlaq menjadi aturan tersendiri, seperti halnya ibadah dan mu'amalat. Dengan demikian, akhlaq yang mulia akan senantiasa muncul menyertai pelaksanaan hukum lainnya. Ketika seorang sholat, sifat khusyu' akan menyertainya. Keadilan akan menyertai sifat seorang hakim yang memberi keputusan dalam peradilan. Demikian pula kejujuran akan menjadi sifat seorang muslim dalam bermu'amalah.

Meski demikian dalam penelitian ini ketaatan beragama ini hanya dibatasi dalam ketaatan berupa kesungguhan dan orientasinya untuk melaksanakan 3 (tiga) kategori yang menyangkut ibadah ritual, fiqh muammalah, dan kesalehan sosial. Yang termasuk dalam ibadah ritual adalah kelima rukun Islam: Syahadat, Shalat, Puasa, Zakat, dan Ibadah Haji. Kategori fiqh 
muammalah menyangkut hukum-hukum Islam: halal, haram, mubah dalam aktifitas bermuammalah. Sedangkan kesalehan sosial adalah berkait aktifitas bermasyarakat, pergaulan dengan alim ulama, dan dukungan pada kegiatan syiar Islam.

3.2 Iklim Kerja

Menurut De Bettignies, H.CI. dari INSEAD, suatu sekolah bisnis di Fountain Blue, Perancis dalam Atmosoeprapto (2001:7477), mengemukakan ada 9 ukuran yang dapat dijadikan parameter untuk menilai iklim kerja yang kondusif yaitu:

a) Kepatuhan (Comformity).

Ada hambatan-hambatan dalam perusahaan yang dirasakan oleh karyawan, seperti banyaknya peraturan-peraturan, prosedur, kebijaksanaan, dan pelaksanaan kerja yang harus dipatuhi, membuat suasana kerja (iklim) menjadi tidak nyaman. Karyawan merasa kebebasannya terlalu dihambat, ini justru bisa mengurangi kemandirian karyawan.

b) Reaksi atau respon (Reactance).

Struktur perusahaan yang dirasakan terlalu kaku. Orang lebih suka mengendalikan diri sendiri (individual control) dan merasakan kebebasannya. Kekakuan struktur perusahaan ini bisa menimbulkan reaksi karena dirasakan terlalu birokrasi dan bisa menjadi bumerang bagi perusahaan.

c) Tanggung jawab (Responsibility).

Bagaimana karyawan merasakan tanggung jawab secara individu yang dilimpahkan padanya, bahwa mereka bisa melaksanakan apa yang menjadi kewajibannya tanpa harus dicek oleh atasannya setiap saat harus membuat keputusan (decision making).

d) Pengambilan Resiko (Risk Taking).

Kemauan manajemen untuk mengambil resiko dalam mengoperasikan bisnis tidak memberikan tantangan dan orang menjadi tidak terdorong atau terangsang untuk mengambil resiko. Karyawan harus juga diberikan tantangan untuk berani menghadapi dan mengambil resiko.

e) Standar atau baku (Standards).

Penekanan bahwa karyawan harus melakukan pekerjaannya dengan baik, penekanan pada pencapaian sasaran, membuat perasaan kurang menyenangkan pada karyawan. Lebih 
baik menekankan pada perbaikan kinerja. Hari ini lebih baik dari hari kemarin dan hari esok lebih baik dari hari ini.

f) Ganjaran (Reward).

Karyawan akan lebih merasa fair (adil) apabila mereka juga menerima ganjaran atas kerja baiknya, tidak hanya mendapat hukuman bila berbuat kesalahan. Ganjaran tidak selalu bersifat material atau finansial, tetapi justru lebih baik bersifat mental. Ganjaran yang bersifat material merangsang karyawan dari luar (outside-in) tidak akan bersifat "langgeng", sebaliknya ganjaran yang bersifat mental (penghargaan, pujian, peningkatan tanggung jawab) akan menimbulkan rangsangan pada karyawan dari dalam (inside-out), sehingga bisa memotivasi diri dan akan lebih "langgeng".

g) Kejelasan (Clarity).

Tingkatan dimana karyawan merasakan bahwa segala sesuatu diorganisasikan dengan baik, daripada yang tidak bisa dilaksanakan, rancu, bertele-tele. Tanggung jawab dan kewenangan setiap karyawan harus diklarifikasikan dengan jelas.

h) Semangat Tim (Team Spirit).

Perasaan bahwa dalam perusahaan ada "anak-anak manis" (ABS) harus ditiadakan. Harus diciptakan kelompok kerja yang bisa bekerja sama secara efektif. Saling pengertian dan saling membantu harus ditumbuhkan, sehingga tidak ada lagi "Superman" (pahlawan), tetapi yang ada hanya "Super Team" (tim yang hebat). Semangat kebersamaan ini orang Perancis menyebutnya "Esprit de Corps".

i) Kehangatan (Warmth).

Dapat dirasakan kesetiakawanan dan saling percaya di antara karyawan. Ada hubungan yang hangat (akrab) di antara manajemen dengan karyawan dalam perusahaan.

Apabila ukuran-ukuran tersebut diupayakan untuk menciptakan suasana (iklim) kerja yang kondusif, maka lingkungan kerja benar-benar dapat dirasakan sebagai tempat menyenangkan (enjoyable) dan meningkatkan kinerja karyawan pada akhirnya diharapkan kinerja bisnis juga meningkat.

2. Kinerja Bisnis

Terdapat banyak ukuran atau indikator yang telah digunakan para ahli dalam menentukan kinerja sebuah bisnis. Ma'ruf (2006) dalam penelitiannya menilai kinerja bisnis lembaga 
keuangan Baitut Tamwil Muhammadiyah (BTM) berdasarkan perkembangan asset, volume usaha, dan kelanggengan usaha.

Sementara itu besarnya laba usaha atau jumlah keuntungan merupakan pencerminan tingkat keberhasilan usaha suatu perusahaan (Riyanto, 1981: 25). Seperti ditulis Suyatno (2006) semakin besar tingkat keuntungan, maka semakin baik kondisi perusahaan dan mempunyai peluang besar untuk dapat berkembang. Keuntungan (profit) disimbolkan $\pi$ adalah selisih antara penerimaan total (TR) dengan biaya total (TC), dapat ditulis: $\pi=\mathrm{TR}$ - TC. Ada tercermin tiga hubungan yang perlu diperhatikan yaitu: bila TR < TC maka л <0; nilai TR > TC maka л $>0$; dan bila TR $=\mathrm{TC}$ maka $\pi=0$. Total revenue merupakan hasil perkalian dari volume penjualan dan harga jual per unit. Total cost merupakan hasil perkalian antara volume penjualan dengan biaya per unit produk yang dijual.

Lebih lanjut keuntungan yang diperoleh juga ditentukan oleh jumlah modal dan tenaga kerja. Modal adalah bagian yang penting dalam suatu usaha (Riyanto, 1981: 27). Tenaga kerja atau pekerja adalah orang yang melakukan suatu pekerjaan dengan harapan mendapatkan balas jasa tertentu.

Dari sisi internal kepuasan kerja merupakan salah satu kontributor penting bagi terciptanya efektifitas bisnis. Kepuasan kerja karyawan yang tinggi akan memberikan kontribusi pada rendahnya tingkat turn over dan kemangkiran karyawan (Spector, 1997). Kepuasan kerja karyawan juga akan berdampak pada tingkat komitmen karyawan (Stum, 1999) dan akan berdampak juga pada kinerja (Wood, 1998).

Kepuasan kerja memiliki hubungan yang sangat erat dengan budaya organisasi walaupun keduanya adalah konsep yang berbeda (Gibson, 1987, Finck, Timmer \& Mennnes, 1998). Budaya organisasi menetapkan tapal batas; membawa identitas anggota organisasi; mempermudah timbulnya komitmen yang lebih luas dari kepentingan individual; meningkatkan kemantapan sistem sosial, serta mekanisme pembuat makna dan kendali pembentuk sikap serta perilaku karyawan (Robbins 1996).

Sejalan dengan Ma'ruf (2006) yang merinci faktor-faktor: Motivasi, Strategi, Modal, Komitmen Karyawan, Pelayanan Prima, Regulasi, dan Pesaing sebagai faktor yang berpengaruh signifikan terhadap variable tetap kinerja lembaga bisnis. 
Dengan demikian, disinilah akan menarik untuk dilihat bagaimana pengusaha muslim yang membawa akhlakul karimah sebagai manifestasi ketaatannya kepada Agamanya mampu membawa budaya yang khas. Budaya tersebut akan berpengaruh terhadap kinerja bisnis yang dijalankan.

\section{KERANGKA PEMIKIRAN}

Pengusaha yang menjalankan bisnis memiliki prilaku dan sikap yang akan mempengaruhi bahkan menentukan identitas bisnisnya. Identitas yang dapat dikatakan merupakan cerminan budaya organisasi/lembaga bisnisnya akan menentukan bagi kelangsungan perkembangan bisnis tersebut. Dalam tataran yang lebih luas ia juga menentukan kelanggengan dan kemajuan hubungan dengan dunia luar, dalam lingkungan dan mitra bisnisnya. Oleh karena itu ketaatan beragama menjadi faktor yang integral dalam menentukan kinerja bisnis seorang pengusaha.

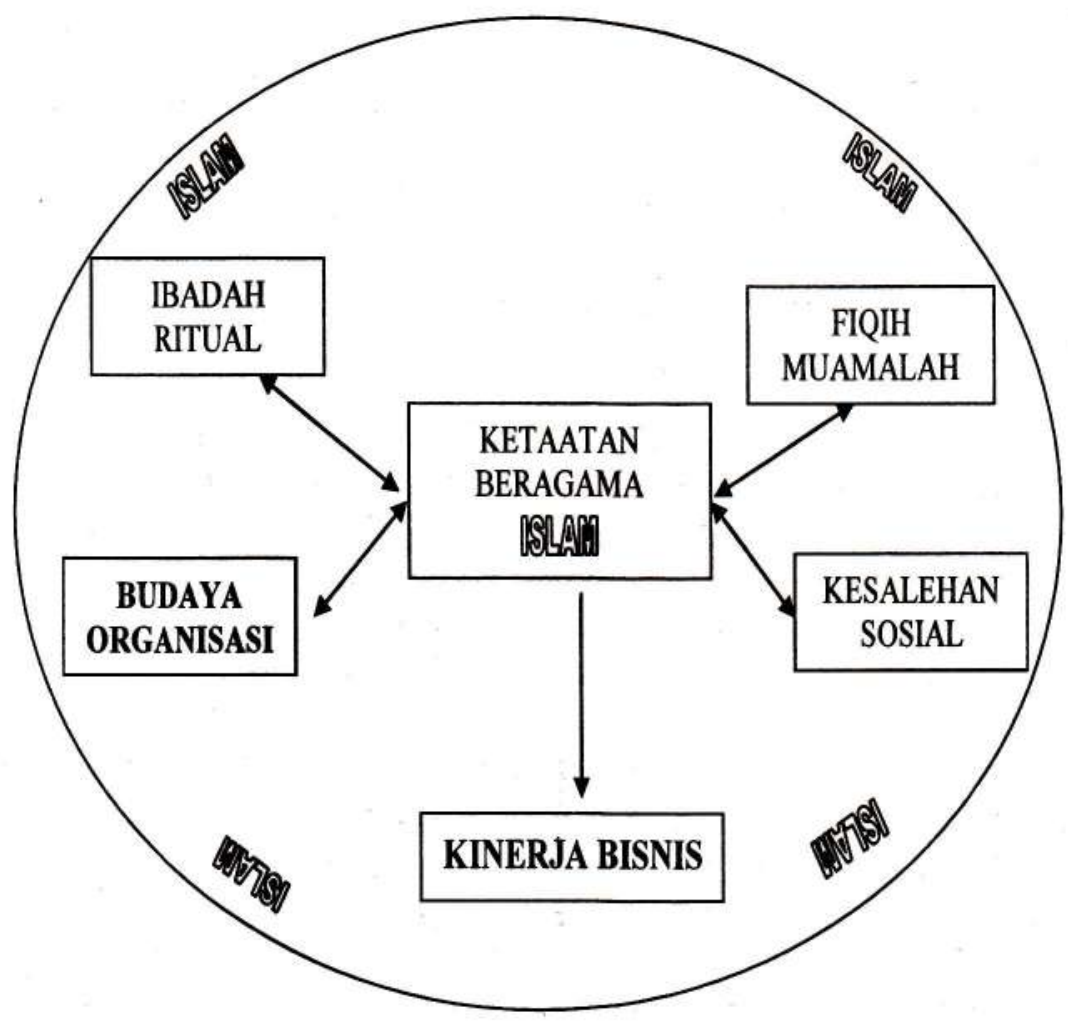




\section{METODE PENELITIAN}

1. Pengambilan Sampel.

Sampel diambil dengan menggunakan metode simple random sampling dengan kerangka sample (sample frame) yaitu berupa daftar sebagaian besar pengusaha yang sesuai denga kriteria yang diinginkan. Penyusunan kerangka sample dengan berbagai pendekatan yang dapat dilakukan, antara lain dengan melihat besarnya volume usaha, jenis usaha, lingkup bisnis dan sebagainya.

2. Metode Pengumpulan Data

Pengumpulan data dilakukan dengan metode wawancara secara langsung dengan bertatap muka dilengkapi daftar peranyaan/kuisioner.

3. Identifikasi Variabel dan Definisi Operasional

Variabel penelitian adalah apa yang menjadi titik perhatian dalam penelitian ini, yang bertujuan untuk menguji adanya tidaknya hubungan antar variabel. Adapun variabel pada penelitian ini adalah Variabel Independen (reflikasi dari ketaatan beragama seorang pengusaha yang terwujud dalam pelaksanaan ibadah ritual, fiqih muamalah, kesalehan sosial dan pelaksanaan manajemen iklim kerja) serta Variabel dependen (pencapaian kinerja bisnis pengusaha yang dilihat berdasarkan peningkatan laba, peningkatan omzet penjualan, bertambahnya jumlah pelannggan, dan penambahan lokasi usaha).

4. Metode Analisis Statistik

Uji Validitas (test of validity)

Uji validitas dalam penelitian ini dilakukan untuk mengetahi apakah kuesioner yang disiapkan sebagai alat pengumpul data telah dapat mengukur variabel yang ingin diukur. Arikunto (1998:111) menyatakan bahwa uji validitas dapat dilakukan dengan cara menghitung korelasi antara masing-masing pertanyaan (item) dengan skor total. Teknik ini disebut dengan korelasi product moment atau korelasi Pearson. Arikunto (1998:111) menyatakan suatu instrumen (item pertanyaan) dikatakan valid apabila terdapat korelasi positif dan peluangnya tidak melebihi tingkat siginifikansi a sebesar 0,05 . Validitas suatu instrumen dapat juga diketahui dengan membandingkan $r$ hitung dengan $r$ tabel. Apabila $r$ hitung lebih besar dari $r$ tabel, maka suatu instrumen dapat dikatakan valid, dan apabila $\mathbf{r}$ hitung lebih kecil dari $r$ tabel, maka suatu instrumen dapat dikatakan tidak valid. 
Uji Reliabilitas

Masri Singarimbun dan Sofyan Effendi (1995:144) dalam bukunya menyatakan bahwa "Reliabilitas adalah indeks yang menunjukkan sejauh mana suatu alat pengukur dapat dipercaya atau dapat diandalkan. Bila suatu alat pengukur dipakai dua kali untuk mengukur gejala yang sama dan hasil pengukuran yang diperoleh relatif konsisten, maka alat pengukur tersebut reliabel. Dengan kata lain, reliabilitas menunjukkan konsistensi suatu alat ukur di dalam mengukur gejala yang sama". Metode yang digunakan untuk uji ini adalah metode Alpha Cronbach. Menurut Uma Sekaran (1992:52), jika nilai alpha antara 0,8 - 10 dikategorikan reliabilitas baik, nilai alpha antara 0,6 - 0,79 dikategorikan reliabilitas diterima, nilai alpha $<0,6$ dikategorikan reliabilitas kurang baik atau tidak diterima.

Untuk mempermudah perhitungan uji validitas dan reliabilitas, maka digunakan perangkat lunak komputer (software) program SPSS (Statistical Product and Division Solutions) versi 11.0 for Windows (Santoso, 2003:10).

Korelasi Kendall's Tau

Penggunaan korelasi Kendall's Tau dimaksudkan untuk memenuhi tujuan dari penelitian ini, yaitu untuk mengetahui hubungan dari variabel independen terhadap variabel dependen. Langkah untuk menjawab masalah dari penelitian ini adalah dengan menguji hubungan dari variable-variabel independen $(X)$ terhadap variabel dependen $(\mathrm{Y})$ secara parsial. Pengujian ini juga untuk melihat dari keempat variabel independen yang ada, mana yang memiliki hubungan yang kuat dengan variabel dependen.

\section{HASIL PENELITIAN}

1. Karakteristik Responden.

Berdasarkan hasil penyebaran kuesioner maka distribusi responden yang meliputi jenis kelamin, usia, masa kerja, dan tingkat pendidikan dapat dijabarkan dalam tabel 1 sampai tabel 4 dibawah ini :

Tabel 1. Distribusi Responden Berdasarkan Jenis Kelamin.

\begin{tabular}{|c|c|c|c|}
\hline No. & Jenis Kelamin & Jumlah Responden & Persentase (\%) \\
\hline 1. & Laki-Laki & 24 & $80 \%$ \\
\hline 2. & Perempuan & 6 & $20 \%$ \\
\hline & Total & 30 & $100 \%$ \\
\hline
\end{tabular}

Sumber : Data primer diolah, 2004 
Berdasarkan tabel 1 tersebut di atas, terlihat bahwa dari 30 responden terdiri dari 24 orang laki-laki atau sebanyak $80 \%$ dan 6 orang perempuan atau $20 \%$, hal ini menunjukan adanya kecendrungan bahwa lebih banyak melakukan kegiatan usaha atau bisnis adalah laki-laki dan hal ini sudah sepatutnya terjadi, karena laki-laki memang memiliki kelabihan jika dibandingkan dengan wanita, sehingga laki-laki lebih mampu untuk melakukan kegiatan usaha. Allah SWT berfirman :

...oleh karena Allah telah melebihkan sebagian mereka (laki-laki) atas sebagian yang lain (wanita).....(QS. Annisa: 34)

Kemudian sebanyak $20 \%$ responden adalah pengusaha wanita, dari hasil wawancara dapat diperoleh kesimpulan bahwa wanita-wanita tersebut menjadi pengusaha lebih dikarenakan meneruskan usaha yan selama ini telah dirintis oleh suami mereka maupun karena warisan orang tua sementara saudara laki-laki mereka lebih tertarik pada pekerjaan lain.

Rasulullah SAW bersabda :

"Kalau dia bekerja untuk menghidupi anak-anaknya yang masih kecil, itu adalah fi sabilillah; Kalau ia bekerja untuk menghidupi keuda orang tuanya yang lanjut usia, itu adalah fi sabilillah; Kalau ia bekerja sendiri agar tidak meminta-minta, itu juga fi sabilillah" (HR. Ath-Thabrani)

Tabel 5.2. karakteristik Responden Berdasarkan Usia.

\begin{tabular}{|c|c|c|c|}
\hline No. & Usia Responden & Jumlah Responden & Persentase (\%) \\
\hline 1. & $<20$ th & 1 & $3,33 \%$ \\
\hline 2. & $21-45$ th & 17 & $56,7 \%$ \\
\hline 3. & $>45$ th & 12 & $40 \%$ \\
\hline \multicolumn{2}{|c|}{ Total } & 30 & $100 \%$ \\
\hline
\end{tabular}

Sumber : Data primer diolah,2006

Tabel 2 tersebut memperlihatkan bahwa Dari 100 responden, $56,7 \%$ atau sebanyak 17 orang responden berusia 21 sampai 45 tahun karena usia ini merupakan usia produktif dan pada usia ini pula semangat dan motivasi kerja sedanga tinggi-tingginya sehingga dengan semangat dan motivasi yang ini mampu membawa usaha yang digeluti dapat mencapai kinerja bisnis yang optimal. 
Sebanyak $3.33 \%$ atau 1 (satu) orang responden masih berusia dibawah 20 tahun, dan sisanya sebanyak $40 \%$ berusia diatas 45 tahun. Hal ini menunjukan bahwa rentang usia para responden yang cukup berbeda, namun menunjukan adanya semangat untuk berusaha secara sungguh dari usia muda hingga usia dewasa. Rasulullah SAW bersabda "

"Bekerjalah kamu untuk duina seolah-olah engkau hidup selama-lamanya, dan bekerjalah kamu untuk akhirat, seolah-olah kamu akan mai esok hari." (HR. Bukhari Muslim)

Tabel 3. Karakteristik Responden Berdasarkan Status Pernikahan

\begin{tabular}{|c|l|c|c|}
\hline No. & Statuts Pernikahan & Jumlah Responden & Persentase (\%) \\
\hline 1. & Menikah & 26 & $86,67 \%$ \\
\hline 2. & Belum Menikah & 4 & $13,33 \%$ \\
\hline \multicolumn{2}{|c|}{ Total } & 30 & $100 \%$ \\
\hline
\end{tabular}

Sumber : Data primer diolah, 2006

Tabel 3 memperlihatkan bahwa sebanyak 26 orang responden atau sebesar $86,67 \%$ dari total responden memiliki status perniakahan sudah menikah dan sisanya belum menikah. Hal ini menunjukan bahwa sebesar $86,67 \%$ responden adalah kelompok muslim yang matang dan memiliki tanggung jawab yang tinggi terhadap kewajiban nya kepada Allah SWT tentang kewajiban berumah tangga apabila sudah mampu mencari nafkah.

Tim Multitama Communications dalam Islamic Business Strategy for Entrepreneurship $(2006 ; 3)$ mengatakan bahwa apabila seseorang memelihara kemaluannya maka ia akan bisa menjadi seorang pengusaha yang sukses.

Allah SWT berfirman dalam surat Al-Mukminun ayat 1, ayat 2 , ayat 5 dan 6 :

"Sesungguhnya beruntunglah orang yang beriman,yaitu oranng orang-orang yang khusu' dalam shalatnya, dan orang-orang yang menjaga kemaluanya, kecuali terhadap isteri mereka....(QS. AlMukminun, 1,2, 5,dan 6)

Tabel 4. Karakteristik Responden Berdasarkan Tingkat Pendidikan.

\begin{tabular}{|c|l|c|c|}
\hline No. & Tingkat Pendidikan & Jumlah Responden & Persentase (\%) \\
\hline 1. & SD & 1 & $3,33 \%$ \\
\hline 2. & SMP & 2 & $6,67 \%$ \\
\hline
\end{tabular}


Hubungan antara Ketaatan Beragama dengan Kinerja Bisnis

\begin{tabular}{|c|l|c|c|}
\hline 3. & SLTA & 16 & $53,33 \%$ \\
\hline 4 & SARJANA & 11 & $36,67 \%$ \\
\hline \multicolumn{2}{|c|}{ Total } & 30 & $100 \%$ \\
\hline
\end{tabular}

Sumber : Data primer diolah, 2006

Tabel 4 tersebut diatas menunjukan bahwa lebih dari $50 \%$ responden memiliki latar belakang belakang pendidikan yang tinggi yakni sebesar $53,33 \%$ sebanyak 16 responden memiliki latar belakang pendidikan SLTA dan sebesar 36,67\% sebanyak 11 responden, hal menunjukan bahwa sebagian besar responden memiliki kemampuan akademik yang mendukung mereka untuk dapat mengembangkan usaha atau bisnis mereka.

\section{Analisis Statistik Inferensial}

Uji Instrumen Penelitian

Hasil uji validitas dan reliabilitas menunjukkan bahwa seluruh item pertanyaan yang digunakan adalah valid dan reliabel. Oleh karena itu, kuisioner yang ada dalam penelitian ini dapat dinyatakan layak sebagai instrument untuk mengukur variabel, pada tabel 5 berikut ini disajikan hasil perhitungan dari Uji Validitas dan reliabilitas.

Tabel 5. Rekapitulasi Hasil Uji Validitas dan Reliabilitas variabel.

\begin{tabular}{|c|c|c|c|c|l|}
\hline Var & $\begin{array}{c}\text { Butir } \\
\text { (item) }\end{array}$ & $\begin{array}{c}\text { Koefisien } \\
\text { Korelasi } \\
\text { (product } \\
\text { Moment0 }\end{array}$ & Keputusan & $\begin{array}{c}\text { Koefisien } \\
\text { Alpha }\end{array}$ & Keputusan \\
\hline $\mathrm{X}_{1}$ & 1 & 0,882 & VALID & 0.8789 & RELIABEL \\
& 2 & 0,836 & VALID & & \\
& 3 & 0,861 & VALID & & \\
& 4 & 0,846 & VALID & & \\
& 5 & 0.833 & VALID & & \\
& 6 & 0.889 & VALID & & \\
& 7 & 0.897 & VALID & & \\
$\mathrm{X}_{2}$ & 8 & 0.789 & VALID & & \\
& 1 & 0.852 & VALID & 0.8565 & RELIABEL \\
\hline
\end{tabular}


Abdurrahman Sadikin dan Satira Yusuf

\begin{tabular}{|c|c|c|c|c|c|}
\hline $\mathrm{X}_{3}$ & 3 & 0.876 & VALID & & \\
& 1 & 0.862 & VALID & 0.9871 & RELIABEL \\
& 2 & 0.874 & VALID & & \\
& 3 & 0.813 & VALID & & \\
$\mathrm{X}_{4}$ & 4 & 0.8123 & VALID & & \\
& 5 & 0.8456 & VALID & & \\
& 1 & 0.8256 & VALID & 0.8494 & RELIABEL \\
& 2 & 0.886 & VALID & & \\
& 3 & 0.874 & VALID & & \\
& 4 & 0.881 & VALID & & \\
& 5 & 0.865 & VALID & & \\
& 6 & 0.786 & VALID & & \\
& 7 & 0.873 & VALID & & \\
& 8 & 0.796 & VALID & & \\
$\mathrm{Y}$ & 9 & 0.799 & VALID & & \\
& 1 & 0.753 & VALID & 0.9513 & RELIABEL \\
& 2 & 0.851 & VALID & & \\
& 3 & 0.861 & VALID & & \\
& 4 & 0.888 & VALID & & \\
& 5 & 0.882 & VALID & & \\
\hline
\end{tabular}

Sumber : Data Primer diolah, 2006

\section{Hasil Uji Korelasi Kendall's Tau}

Secara ringkas, hasil korelasi Kendall's Tau antara Ketaatan Beragama ketaatan beragama seorang pengusaha (yang terwujud dalam pelaksanaan ibadah ritual, fiqih muamalah, kesalehan sosial dan pelaksanaan manajemen iklim kerja), dengan pencapaian kinerja bisnis pengusaha (yang dilihat berdasarkan peningkatan laba, peningkatan omzet penjualan, bertambahnya jumlah pelannggan, dan penambahan lokasi usaha) dapat dilihat pada tabel 6 berikut ini : 
Tabel 6. Hasil Perhitungan Analisis Korelasi Kendall Tau dan Korelasi Spearman's

\begin{tabular}{|c|c|c|c|c|c|c|c|}
\hline \multicolumn{8}{|c|}{ Corre lations } \\
\hline & & & $\begin{array}{l}\text { IBADAH } \\
\text { RITUAL }\end{array}$ & $\begin{array}{c}\text { FIQIH } \\
\text { MUAMALAH }\end{array}$ & $\begin{array}{l}\text { KESALEHAN } \\
\text { SOSIAL }\end{array}$ & $\begin{array}{l}\text { MANAJEMEN } \\
\text { BUDAYA } \\
\text { KERJA }\end{array}$ & $\begin{array}{l}\text { KINERJA } \\
\text { BISNIS }\end{array}$ \\
\hline \multirow[t]{5}{*}{$\begin{array}{l}\text { Kendall's } \\
\text { tau_b }\end{array}$} & $\begin{array}{l}\text { IBADAH } \\
\text { RIUUAL }\end{array}$ & $\begin{array}{l}\text { Correlation Coefficient } \\
\text { Sig. (2-taled) } \\
\mathrm{N} \\
\end{array}$ & $\begin{array}{r}1.000 \\
30 \\
\end{array}$ & $\begin{array}{r}.226^{*} \\
.040 \\
30 \\
\end{array}$ & $\begin{array}{r}.304^{*} \\
.024 \\
30 \\
\end{array}$ & $\begin{array}{r}.132^{*} \\
.042 \\
30 \\
\end{array}$ & $\begin{array}{r}.102^{*} \\
.045 \\
30 \\
\end{array}$ \\
\hline & $\begin{array}{l}\text { FIQIH } \\
\text { MUAMALAH }\end{array}$ & $\begin{array}{l}\text { Correlation Coefficient } \\
\text { Sig. (2-taled) } \\
\mathrm{N}\end{array}$ & $\begin{array}{r}.226^{\circ} \\
.040 \\
30 \\
\end{array}$ & $\begin{array}{r}1.000 \\
30 \\
\end{array}$ & $\begin{array}{r}.099^{*} \\
.049 \\
30 \\
\end{array}$ & $\begin{array}{r}.299^{\circ} \\
.036 \\
30 \\
\end{array}$ & $\begin{array}{r}.388^{*} \\
.022 \\
30 \\
\end{array}$ \\
\hline & $\begin{array}{l}\text { KESALEHAN } \\
\text { SOSIAL }\end{array}$ & $\begin{array}{l}\text { Correlation Coefficient } \\
\text { Sig. (2-taled) } \\
\mathrm{N}\end{array}$ & $\begin{array}{r}.304^{*} \\
.024 \\
30\end{array}$ & $\begin{array}{r}.099^{\circ} \\
.049 \\
30\end{array}$ & $\begin{array}{r}1.000 \\
30\end{array}$ & $\begin{array}{r}.129 \\
.064 \\
30\end{array}$ & $\begin{array}{r}.076^{*} \\
.046 \\
30\end{array}$ \\
\hline & $\begin{array}{l}\text { MANAJEMEN } \\
\text { BUDAYA } \\
\text { KERJA }\end{array}$ & $\begin{array}{l}\text { Correlation Coefficient } \\
\text { Sig. (2-taled) } \\
\mathrm{N}\end{array}$ & $\begin{array}{r}.132^{*} \\
.042 \\
30 \\
\end{array}$ & $\begin{array}{r}.299^{*} \\
.036 \\
30 \\
\end{array}$ & $\begin{array}{r}.129 \\
.064 \\
30 \\
\end{array}$ & $\begin{array}{r}1.000 \\
30 \\
\end{array}$ & $\begin{array}{r}-.053 \\
.074 \\
30 \\
\end{array}$ \\
\hline & $\begin{array}{l}\text { KINERJA } \\
\text { BISNIS }\end{array}$ & $\begin{array}{l}\text { Correlation Coefficient } \\
\text { Sig. (2-taled) } \\
\mathrm{N}\end{array}$ & $\begin{array}{r}.102^{*} \\
.045 \\
30 \\
\end{array}$ & $\begin{array}{r}.388^{\circ} \\
.022 \\
30 \\
\end{array}$ & $\begin{array}{r}.076^{\circ} \\
.046 \\
30 \\
\end{array}$ & $\begin{array}{r}-.053 \\
.074 \\
30 \\
\end{array}$ & $\begin{array}{r}1.000 \\
30 \\
\end{array}$ \\
\hline \multirow[t]{5}{*}{$\begin{array}{l}\text { Spearman's } \\
\text { tho }\end{array}$} & $\begin{array}{l}\text { IBADAH } \\
\text { RITUAL }\end{array}$ & $\begin{array}{l}\text { Correlation Coefficient } \\
\text { Sig. (2-taled) } \\
\mathrm{N} \\
\end{array}$ & $\begin{array}{r}1.000 \\
30 \\
\end{array}$ & $\begin{array}{r}.227^{*} \\
.046 \\
30 \\
\end{array}$ & $\begin{array}{r}.309^{\circ} \\
.029 \\
30 \\
\end{array}$ & $\begin{array}{r}.135^{*} \\
.043 \\
30 \\
\end{array}$ & $\begin{array}{r}.105^{*} \\
.046 \\
30 \\
\end{array}$ \\
\hline & $\begin{array}{l}\text { FIQIH } \\
\text { MUAMALAH }\end{array}$ & $\begin{array}{l}\text { Correlation Coefficient } \\
\text { Sig. (2-taled) } \\
\mathrm{N}\end{array}$ & $\begin{array}{r}227^{*} \\
.046 \\
30 \\
\end{array}$ & $\begin{array}{r}1.000 \\
30 \\
\end{array}$ & $\begin{array}{r}.101^{*} \\
.046 \\
30 \\
\end{array}$ & $\begin{array}{r}.301^{*} \\
.044 \\
30 \\
\end{array}$ & $\begin{array}{r}.421^{*} \\
.021 \\
30 \\
\end{array}$ \\
\hline & $\begin{array}{l}\text { KESALEHAN } \\
\text { SOSIAL }\end{array}$ & $\begin{array}{l}\text { Correlation Coefficient } \\
\text { Sig. (2-taled) } \\
\mathrm{N}\end{array}$ & $\begin{array}{r}.309^{*} \\
.029 \\
30\end{array}$ & $\begin{array}{r}.101^{\circ} \\
.046 \\
30\end{array}$ & $\begin{array}{r}1.000 \\
30\end{array}$ & $\begin{array}{r}.137 \\
.037 \\
30\end{array}$ & $\begin{array}{r}.178^{*} \\
.038 \\
30\end{array}$ \\
\hline & $\begin{array}{l}\text { MANAJEMEN } \\
\text { BUDAYA } \\
\text { KERJA }\end{array}$ & $\begin{array}{l}\text { Correlation Coefficient } \\
\text { Sig. (2-taled) } \\
\mathrm{N}\end{array}$ & $\begin{array}{r}.135^{*} \\
.043 \\
30 \\
\end{array}$ & $\begin{array}{r}.301^{*} \\
.044 \\
30 \\
\end{array}$ & $\begin{array}{r}.137 \\
.037 \\
30 \\
\end{array}$ & $\begin{array}{r}1.000 \\
30 \\
\end{array}$ & $\begin{array}{r}-.072 \\
.063 \\
30 \\
\end{array}$ \\
\hline & $\begin{array}{l}\text { KINERJA } \\
\text { BISNIS }\end{array}$ & $\begin{array}{l}\text { Correlation Coefficient } \\
\text { Sig. (2-taled) } \\
\mathrm{N}\end{array}$ & $\begin{array}{r}.105^{\star} \\
.046 \\
30 \\
\end{array}$ & \begin{tabular}{r|}
$.421^{\circ}$ \\
.021 \\
30 \\
\end{tabular} & $\begin{array}{r}.178^{\circ} \\
.038 \\
30 \\
\end{array}$ & $\begin{array}{r}-.072 \\
.063 \\
30 \\
\end{array}$ & $\begin{array}{r}1.000 \\
30 \\
\end{array}$ \\
\hline
\end{tabular}

*. Correlation is significant at the .05 level (2-taled).

Dari hasil uji korelasi Kendall's Tau yang dilakukan, tampak bahwa hampir semua variabel penelitian ini dapat dinyatakan memiliki korelasi jika memiliki sign (2-tailed) yang lebih kecil dari tingkat toleransi kesalahan yang diperkenankan yaitu sebesar 0,05 (5\%).

Adapun hasil dari analisis data dengan menggunakan analisis korelasi Kendall's Tau adalah sebagai berikut:

1. Korelasi Ibadah Ritual dengan Fiqih Muamalah

Hasil perhitungan Korelasi Kendall Tau pada Tabel 6 menunjukan bahwa hubungan/korelasi antara variabel ibadah ritual dengan variabel fiqih muamalah memiliki hubungan yang cukup signifikan, hal ini bisa dilihat dari besarnya nilai signnifikansi $t$ (sign $t$ ) two-tailed sebesar 0,040 yang lebih kecil dari toleransi kesalahan yang diperkenankan $(0,05)$ (Santoso: 2005,337). Jadi dapat dikatakan bahwa hubungan antara variabel ibadah ritual dengan variabel Fiqih Muamalah 
memiliki korelasi yang signifikan. Besarnya hubungan korelasi antara variabel ibadah ritual dengan variabel fiqih muamalah ditunjukan oleh nilai koefisien korelasi (r) sebesar 0,226.

Angka koefisien korelasi sebesar 0,226 menunjukan arah hubungan yang positif, dimaksudnya adalah apabila dalam penelitian ini seorang mukmin meningkatkan kualitas pelaksanaan ibadah ritual mereka maka besar kemungkinan tingkat atau kualitas fiqih muamalah mereka juga akan semakin kuat.

Allah SWT berfirman dalam surah Al-Mukmiun ayat 2-3:

" yaitu orang-orang yang khusu' dalam sholatnya (2); dan orang orang yang menjauhkan diri dari (perbuatan dan perkataan) yang tiada berguna (3)"

Ayat tersebut menggambarkan dengan jelas hubungan atau keterkaitan orang yang melaksanakan ibadah ritual secara sungguh-sungguh pasti juga akan diikuti dengan perbuatan untuk menghindari hal-hal sia-sia.

2. Korelasi Ibadah Ritual dengan Kesalehan Sosial

Hasil perhitungan Korelasi Kendall Tau pada Tabel 6 menunjukan bahwa hubungan/korelasi antara pelaksanaan ibadah ritual dengan dengan variabel kesalehan sosial memiliki hubungan yang cukup signifikan, hal bisa dilihat dari besarnya nilai signnifikansi $t$ (sign $t$ ) two-tailed sebesar 0,024 yang lebih kecil dari toleransi kesalahan yang diperkenankan $(0,05)$ (Santoso: 2005,337). Jadi dapat dikatakan bahwa hubungan antara variabel ibadah ritual dengan variabel kesalehan sosial memiliki korelasi yang signifikan.

Besarnya hubungan korelasi antara variabel ibadah ritual dengan variabel kesalehan sosial ditunjukan oleh nilai koefisien korelasi (r) sebesar 0,304. Arah hubungan yang ditunjukan koefisien korelasi ini memperliatkan arah yang posisti atau searah artinya jika pelaksanaan ibadah ritual meningkat maka tingkat kesalehan sosial seorang pengusaha mukmin juga akan meningkat. Artinya seorang pengusaha yang rajin sholat wajib maupun sunat, rajin melaksanakan ibadah-ibdah ritual yang diwajibkan maupun disunatkan maka akan memiliki kepedulian sosial ang tinggi pula.

Dalam surah Al-Mukminun ayat 1, ayat 2 dan ayat 4 Allah SWT memperlihatkan hubungan antara variabel ibadah ritual dengan keslehan sosial. 
"Beruntunglah orang-orang mukmin: yaitu orang-orang yang khususk dalm sholatnya: dan orang-orang yang megeluarkan zakat" (QS. Al-Mukminun ayat 1,2 dan 4)

Berdasarkan ayat tersebut dapat terlihat bahwa seorang mukmin yang beruntung adalah mukmin yang senantiasa khusuk dalam melaksanakan sholat (ibadah ritual) dan juga oran senantiasa mengeluarkan zakat sebagai wujud dari kesalehan sosial.

3. Korelasi Ibadah Ritual dengan Manajemen Budaya Kerja Hasil perhitungan Korelasi Kendall Tau pada Tabel 6 menunjukan bahwa hubungan/korelasi antara variabel ibadah ritual memiliki hubungan yang cukup signifikan dengan variabel Manajemen Budaya Kerja, hal bisa dilihat dari besarnya nilai signnifikansi $t$ (sign $t$ ) two-tailed sebesar 0,042 yang lebih kecil dari toleransi kesalahan yang diperkenankan $(0,05)$ (Santoso: 2005,337). Jadi dapat dikatakan bahwa hubungan antara variabel ibadah ritual dengan variabel Manajemen Budaya kerja memiliki korelasi yang signifikan.

Besarnya hubungan korelasi antara variabel ibadah ritual dengan variabel manajemen budaya kerja ditunjukan oleh nilai koefisien korelasi (r) sebesar 0,132 yang berarti hubungan edua variabel ini memiliki arah yang searah pula, maksudaya adalah seorang Pengusaha Mukmin yang taat yang menjalankan seluruh aktivitas ibadah ritual juga akan berusaha untuk meningkatkan kemapuan manajemen budaya kerja dari kegiatan usaha yang dipimpinnya.

4. Korelasi Ibadah Ritual dengan Kinerja Bisnis

Hasil perhitungan Korelasi Kendall Tau pada Tabel 6 menunjukan bahwa hubungan/korelasi antara variabel ibadah ritual memiliki hubungan yang cukup signifikan dengan variabel kinerja bisnis, hal ini bisa dilihat dari besarnya nilai signnifikansi t (sign $t$ ) two-tailed sebesar 0,045 yang lebih kecil dari toleransi kesalahan yang diperkenankan $(0,05)$ (Santoso: 2005,337). Jadi dapat dikatakan bahwa hubungan antara variabel ibadah ritual dengan variabel kinerja bisnis memiliki korelasi yang signifikan.

Besarnya hubungan korelasi antara variabel ibadah ritual dengan variabel kinerja bisnis ditunjukan oleh nilai koefisien korelasi (r) sebesar 0,102, besarnya nilai koefisien korelasi ini menunjukan bahwa arah hubungan yang positifmaksudnya 
apabila variabel Ibadah Ritual meningkat maka Variabel kinerja bisnis juga akan menguat.

ALLAH SWT dalam surah Al-Mukminun ayat 1-11 mengedepankan 6 prasyarat untuk memperoleh keberuntungan dan kesuksesan oleh seorang mukmin, dimana bila prasyarat ini terpenuhi maka bisa dipastikan kesuksesan (kinerja bisnis) akan dapat diraih.

Kreteria-kreteria tersebut lebih ditekankan pada pelaksanaan ibadah-ibadah ritual, yang dirumuskan dalam poin-poin berikut :

1. Fi shalaatihim khaasy'uun (orang khusu' dalam sholatnya) Sholat merupakan sarana komunikasi seorang hamba dengan Tuhannya, tempat mengadu dan memohon harapan, dan jalur mendekatkan diri kepada Sang Pencipta yang dapat memberikan jalan setiap problema kehidupan. Takbirul ikhram tanda pembuka, menyingkirkan segala godaan karena berhadapan dengan yang Mahakuasa, lidah membaca do'a dan hati meraba makna. Dengan itu, diharapkan jalan kesuksesan terbuka bagi seorang hamba. Tetapi sholat jangan dijadikan tujuan (karena shalat merupakan alat untuk mencapai tujuan). Tujuannya adalah menghindari diri dari perbuatan keji dan munkar, maka harus khusu' juga di luar shalat.

Ciri-ciri khusu' di luar shalat harus peka terhadap kepedulian sosial. Artinya harus berguna bagi orang banyak dan bisa mencintai dirinya sendiri.

2. 'Anil laghwi mu'riduwn (menjauhkan diri dari perbuatan laga)

Setiap hari rajin beramal saleh dan berbuat baik dengan sesama, keluarga, jiran, serta lingkungan. Mengatur waktu dengan disiplin dan tidak melewatinya dengan hampa (alias tanpa makna), melainkan diisi dengan kreativitas dalam rangka mengabdikan diri kepada penciptanya. Juga bisa diartikan sedikit bicara banyak kerja (kerja keras), orang yang ulet, tangguh, dan bersungguh-sungguh untuk mencari nafkah dengan ilmu. Sehingga, tenaga (profesional) akan lebih banyak mendapatkan peluang sukses secara material.

3. Liz zakaati faa'iluun (mengeluarkan zakat)

Mukmin yang memiliki ciri sukses sangat merasa bahwa apa yang dinikmati dalam hidupnya merupakan pemberian dan rahmat ALLAH SWT Swt. Dia sadar ketika lahhir ke dunia 
tidak membawa apa-apa. Karena itu mukmin yang sukses tidak pernah membuat perhitungan kalau memang diperintahkan mensyukuri nikmat-Nya. Serta gemar menyisihkan hartanya sebagai budaya diri, dimana hartanya dizakati, diinfakan, dan disedekahkan.

4. Lifuruujihin haafizhuun (memelihara farajnya)

Nafsunya dipelihara, terkontrol tidak berbuat yang slaah, tidak pernah menempuh jalan ilegal tanpa prosedur akad nikah. Selain mampu meredam nafsu dan melawan rayuan syaitan di dalam qalbu, juga mengupayakan nilai-nilai moral sejauh kemampuan yang ada pada dirinya. Orang yang sukses-kaya materi-tentunya sangat dikhawatirkan sulit menjaga dan memelihara kemaluannya. Maka di dalam masyarakat mapan paling riskan terhadap perzinahan. Karena itu, ALLAH SWT mangeturnya dengan melakukan pernikahan.

5. Ila 'alla azwaajihim (kecuali terhadap istri-istrinya)

Seorang mukmin yang beruntung, tentunya dalam meletakkan kecenderungan (syahwatnya) harus kepada isterinya, sehingga kesuksesan usaha dibarengi dengan kesuksesan rumah tangga. Bahkan kesuksesan seorang mukmin digambarkan ALLAH SWT dalam Al-Quran sebagai pewaris surga yang sekaligus pemenang di dunia dan akhirat.

6. $\mathrm{Li}$ amaawaathigim wa'ahdihim ra'auun (memelihara amahah dan janji)

Mukmin yang mencapai sukses adalah mukmin yang memegang amanah. Amanah terhadap tugas yang diterima, amanah terhadapjanji, amanah terhadap kepercayaan yang diberikan orang lain (terpercaya). Amanah merupakan pilar utama menuju sukses. Pedagang yang jujur dan amanah akan tinggal bersama para nabi, para shiddiq, dan para syuhadah di hari kiamat; (HR. Turmudzi dan Ibnu Majah).

Dalam ayat lain ALLAH SWT berfirman:

"(yaitu) orang-orang yang mendirikan shalat dan menafkahkan sebagian dari rezeki yang kami berikan kepada mereka. Itulah orangorang yang beriman dengan sebenar-benarnya. Mereka akan memperoleh derajat ketinggian di sisi Tuhannya dan ampunan serta rezeki (nikmat) yang mulia." (QS. Al-Anfal: 3-4)

5. Korelasi Fiqih Muamalah dengan Kesalehan Sosial Hasil perhitungan Korelasi Kendall Tau pada Tabel 6 menunjukan bahwa hubungan/korelasi antara variabel Fiqih 
muamalah memiliki hubungan yang cukup signifikan dengan variabel kesalehan sosial, hal ini bisa dilihat dari besarnya nilai signnifikansi t (sign $\mathrm{t}$ ) two-tailed sebesar 0,049 yang lebih kecil dari toleransi kesalahan yang diperkenankan $(0,05)$ (Santoso: 2005,337). Jadi dapat dikatakan bahwa hubungan antara variabel fiqih muamalah dengan variabel Kesalehan sosial memiliki korelasi yang signifikan.

Besarnya hubungan korelasi antara variabel fiqih muamalah dengan variabel kesalehan sosial ditunjukan oleh nilai koefisien korelasi (r) sebesar 0,099 dan menunjukan arah yang positif artinya bila variabel Fiqih Muamalah menguat maka besarnya variabel kesalehan sosial juga akan menguat.

Hubungan positif ini merupakan sebuah indikasi yang menunjukan bahwa apabila seorang melaksanakan kegiatankegiatan yang berhubungan dengan Fiqih muamalah maka secara tidak langsung juga akan menunaikan kewajiban kesalehan sosial.

6. Korelasi Fiqih Muamalah dengan Manajemen Budaya Kerja Hasil perhitungan Korelasi Kendall Tau pada Tabel 6 menunjukan bahwa hubungan/korelasi antara variabel fiqih muamalah dengan manajemen budaya kerja memiliki hubungan yang cukup signifikan, hal bisa dilihat dari besarnya nilai signnifikansi t (sign t) two-tailed sebesar 0,036 yang lebih kecil dari toleransi kesalahan yang diperkenankan $(0,05)$ (Santoso: 2005,337). Jadi dapat dikatakan bahwa hubungan antara variabel fiqih muamalah dengan variabel manajemen budaya kerja memiliki korelasi yang signifikan.

Besarnya hubungan korelasi antara variabel fiqih muamalah dengan variabel manajemen budaya kerja ditunjukan oleh nilai koefisien korelasi (r) sebesar 0,132.

Arah hubungan yang ditunjukan oleh tabel korelasi Kendall Tau menunjukan hubungan yang positif, artinya peningkatan kemampuan menjalankan hal-hal yang berhubungan dengan fiqih Muamalah akan diikuti dengan kemampuan untuk memanajemen budaya kerja yang lebih baik.

Seorang pengusaha muslim yang taat tentunya akan memanfaatkan seluruh waktu yang dimilikinya untuk pengembangan diri dan pengelolaan budaya kerja yang lebih optimal. 
Allah SWT berfirman :

"apakah mereka membagi-bagi rahmat Tuhanmu? Kami telah menentukan antara mereka penghidupan mereka dalam kehidupan dunia, dan kami telah meninggikan sebagian mereka atas sebagian yang lain beberapa derajat, agar sebagian mereka mempergunakan sebagian yang lain," (QS. Az-Zukhruf: 32)

Pengusaha muslim senantiasa berusaha untuk mengaktualitaskan dirinya, melayanianya (antum a'lamu bi umuuri dunyakum), melayani konsumen atau orang-orang yang menaruh harapan kepada kerjanya. Berusaha selalu memberikan pelayanan terbaik kepada orang atau lembaga yang berusaha membantu atau memajukan usahanya. Semuanya dilakukan dengan penuh kesadaran bahwa apa yang dilakukan sebagai pengabdian kepada Yang Maha Menentukan baik semuanya.

7. Korelasi Fiqih Muamalah dengan Kinerja Bisnis

Hasil perhitungan Korelasi Kendall Tau pada Tabel 6 menunjukan bahwa hubungan/korelasi antara variabel fiqih muamalah memiliki hubungan yang cukup signifikan dengan variabel kinerja bisnis, hal bisa dilihat dari besarnya nilai signnifikansi $t$ (sign $t$ ) two-tailed sebesar 0,22 yang lebih kecil dari toleransi kesalahan yang diperkenankan $(0,05)$ (Santoso: 2005,337). Jadi dapat dikatakan bahwa hubungan antara variabel fiqih muamalah dengan variabel kinerja bisnis memiliki korelasi yang signifikan.

Besarnya hubungan korelasi antara variabel fiqih muamalah dengan variabel kinerja bisnis ditunjukan oleh nilai koefisien korelasi (r) sebesar 0,388, arah hubungan yang ditunjukan oleh koefisien korelasi ini juga menunjukan arah yang positif, dimana bila terjadi peningkatan pada variabel fiqih muamalah maka kinerja bisnis juga akan mengalami peningkatan yang signifikan.

Allah SWT berfirman :

"Hai orang-orang yang beriman, sukakah kamu aku tunjukan suatu perniagaan yang dapat menyelamatkan kamu dari azab yang pedih?; (Yaitu) kamu beriman kepada Allah dan Rasul-Nya dan berjihad di jalan Allah dengan harta jiwamu. Itulah yang lebih baik bagi kamu jika kamu mengetahuinya.; niscaya Allah akan mengampuni dosadosamu dan memasukan kamu ke dalam surga yang mengalir di bawahnya sungai-sungai, dan (memasukan kamu) ke tempat tinggal 
yangbaik di dalam Surga'Adn. Itulah keberuntungan yang besar. (QS. As.saff; 10-12)

8. Korelasi Kesalehan Sosial dengan Manajemen Budaya Kerja Menurut tabel 6 Bentuk hubungan dari variabel kesalehan sosial dengan manajemen budaya kerja menunjukan hasil yang tidak siginifikan, karena besarnya nilai sign $\mathrm{t}$ two tailed berada pada angka 0,064 yang lebih besar dari tingkat tolernasi kesalahan yang diperkenankan, maka hubungan variabel kesalehan sosial dengan manajemen budaya kerja tidak signifikan. artinya berapapun atau perubahan yang bagaimanapun tidak akan bisa meningkatkan atau merubah variabel manajemen budaya kerja. Maksudnya adalah bahwa seoarang pengusaha muslim yang taat, yang memiliki kesalehan sosial akan sulit untuk dapat menciptakan manajemen budaya kerja yang baik karena dalam penciptaan manajemen budayakerja yang baik sangat menuntut partisipasi seluruh anggota/pekerja yang terlibat dalam kegiatan usaha.

Kurangnya partisipsi pekerja dalam menciptakan budaya kerja mungkin lebih dikarenakan belum atau kurang gaji yang diterima oleh para pekerja atau bahkan tidak terbayarkannya gaji si Pekerja.

Imam Bukhari meriwayatkan dari Abu Hurairah yanng mengatakan: Rasulullah SAW bersabda :

"Allah SWT. Berfirman: 'Tiga orang yang aku musushi pada hari kiamat nanti, adalah orang yang telah memberikan karena Aku, lalu berkhianat; dan orang yang membeli barang pilihan, lalu ia makan kelebihan harganya; serta orang yang mengontrak pekerja kemudian pekerja tersebut menunaikan transaksinya sedangkan upahnya tidak diberikan"

Karena itulah seorang pengusaha dituntut sesegera mungkin untuk memenuhi kewajibanya kepada para pekerja sehingga akhirnya peran serta seluruh pekerja dalam berkerja sama dapat terealisasikan, karena kerjasama dapat memunculkan suasana saling membantu dalam menangani pekerjaan. Ini akan melahirkan gelombang produktivitas yang luar biasa. Bahkan tidak diperhitungkan manusia, jika ia berpikir dan berbuat sendiri. Itulah sebabnya semangat, energik, dan simbiotik harus selalu terjaga di kalangan karyawan.

9. Korelasi Kesalehan Sosial dengan Kinerja Bisnis

Hasil perhitungan Korelasi Kendall Tau pada Tabel 6 menunjukan bahwa hubungan/korelasi antara variabel 
kesalehan sosial dengan kinerja bisnis memiliki hubungan yang cukup signifikan, hal bisa dilihat dari besarnya nilai signnifikansi $t$ (sign $t)$ two-tailed sebesar 0,046 yang lebih kecil dari toleransi kesalahan yang diperkenankan $(0,05)$ (Santoso: 2005,337). Jadi dapat dikatakan bahwa hubungan antara variabel kesalehan sosial dengan variabel kinerja bisnis memiliki korelasi yang signifikan.

Besarnya hubungan korelasi antara variabel kesalehan sosial dengan variabel kinerja bisnis ditunjukan oleh nilai koefisien korelasi (r) sebesar 0,076. Tanda positif dari besarnya nilai koefisien korelasi ini menunjukan bahwa semakin besar nilai dari variabel kesalehan sosial maka akan semakin besar nilai kinerja bisnis dari penelitian ini.

Berdasarkan nilai koefisien korelasi ini, maka dapat dikatakan orang yang memiliki kesalehan sosial maka akan dapat meningkatkan kinerja bisnisnya, adapun ciri orang yang memiliki kesalehan sosial adalah :

- Suka menyambung tali silaturahim

- Menunaikan zakat, infaq, dan sadaqah (ZIS)

10. Korelasi Manajemen Budaya Kerja dengan Kinerja Bisnis

Hasil perhitungan Korelasi Kendall Tau pada Tabel 6 menunjukan bahwa hubungan/korelasi antara Manajemen budaya kerja dengan kinerja bisnis tidak memiliki hubungan yang signifikan, hal bisa dilihat dari besarnya nilai signnifikansi $t$ (sign $t)$ two-tailed sebesar 0,074 yang lebih besar dari toleransi kesalahan yang diperkenankan $(0,05)$ (Santoso: 2005,337), maka dapat dikatakan bahwa hubungan antara variabel manajemen budaya kerja dengan variabel kinerja bisnis tidak memiliki korelasi yang signifikan.

Tidak adanya hubungan atau korelasi dari kedua variabel ini menunjukan bahwa apabila variabel manajemen budaya kerja mengalami perubahan maka variabel kinerja bisnis tidak akan berubah mengikuti atau berlawanan dengan variabel manajemen budaya kerja.

\section{PEMBAHASAN}

Hasil perhitungan analisis korelasi Kendall Tau pada tabel 6 memperlihatkan bahwa ada 10 (sepuluh) korelasi dari 5 (lima) variabel yang digunakan dalam penelitian ini, dari sepuluh korelasi itu hampir semua korelasi menunjukan hubungan yang 
signifikan, hanya dua korelasi yang tidak memiliki hubungan korelasi.

Korelasi yang dominan adalah korelasi antara variabel fiqih muamalah dengan kinerja bisnis yaitu sebesar 0,388. Besarnya angka koefisien korelasi ini memang masih jauh tingkat korelasi yang kuat yaitu angka koefisien korelasi yang mendekati angka satu (Santoso: 2005,336).

Masih lemahnya korelasi dari beberapa variabel yang digunakan penelitian ini, lebih dikarenakan adanya variabel lain yang juga turut berhubungan dengan kinerja bisnis, diantaranya :

\section{$\sqrt{ }$ Kondisi Sosial Politik}

Keadaan atau kondisi sosial masyarakat memiliki hubungan yang cukup kuat terhadap kinerja bisnis, karena status sosial masyarakat sangat berpengaruh terhadap pola hidup masyarakat, yang pada mulanya masyarakat senang berbelanja pada daerah sendiri tetapi setelah mereka merasakan adanya peningkatan status sosial mereka akhirnya cenderung lebih senang untuk berbelanja ke luar daerah/pulau dengan alasan harga yang dapat lebih murah atau lebih banyak pilihan macam da jenis barang.

Begitu juga dengan keadaan politik suatu daerah, dimana apabila suatu daerah sedang atau akan melaksanakan suatu perayaan pesta politik biasanya masyarakat agak sedikit takut dan khawatir untuk sekedar berbelanja.

Kedua kondisi tersebut diatas pada akhirnya pasti akan menimbulkan suatu pola korelasi terhadap kinerja bisnis para pengusaha muslim di kota Banjarmasin.

$\sqrt{ }$ Siklus Musiman

Sudah menjadi tradisi dalam masyarakat kita bahwa apabila saat menjelang bulan ramadhan, menjelang lebaran, menjelang perayaan kegiatan keagamaan tertentu maka masyarakat cenderung untuk berbelanja secara overlap (berlebih-lebih) sehingga hal pasti akan berhubungan dengan kinerja bisnis dari para pengusaha termasuk pengusaha muslim.

$\sqrt{ }$ Daya Beli Masyarakat

Naik turunnya daya beli masyarakat juga memiliki hubungan yang dengan kinerja bisnis para pengusaha, dimana bila daya beli masyarakat meningkat maka akan memberi korelasi yang positif bagi kinerja bisnis, tetapi bila daya beli masyarakat melemah maka akan memberi korelasi yang yang sebaliknya. 


\section{$\sqrt{ }$ Pola/Sistem Pemasaran}

Pola pemasaran dari para pengusaha juga memiliki korelasi terhadap kinerja bisnis para pengusaha, dimana bila para pengusaha memiliki pola pemasaran sistem diskon maka akan ada korelasi terhadap kinerja bisnis mereka dilihat dari sisi penjualan.

$\sqrt{ }$ Promosi

Kegiatan promosi juga merupakan salah satu variabel yang memiliki korelasi dengan kinerja bisnis, dimana bila promosi gencar dilakukan maka akan usaha yang digeluti lebih dikenal masyarakat luas hingga akhirnya akan berkorelasi secara langsung dengan kinerja bisnis.

\section{KESIMPULAN DAN SARAN}

Berdasarkan pada latar belakang dan pembahasan dalam penelitian ini, maka dapat ditarik beberapa kesimpulan sebagai berikut :

1. Terdapat korelasi yang cukup signifikan antara variabelvariabel ketaatan beragama dengan kinerja bisnis seorang pengusaha muslim.

2. Korelasi yang paling kuat ditunjukan oleh variabel fiqih muamalah dengan kinerja bisnis, yaitu sebesar 0,388 \%.

3. Seorang pengusaha muslim senantiasa berusaha untuk mengaktualisasikan dirinya, melayaninya (antum a'lamu bi umiri dunyakum), melayani konsumen atau orang-orang yang menaruh harapan padanya atau kerjanya (konsumen), serta memberikan pelayanan yang baik kepada orang atau lembaga yang berusaha untuk membantu atau memajukan diri dan usahanya. Namun semuanya itu, ia lakukan dengan penuh kesadaran sebagai pengabdian kepada Yang Maha Menentukan bagi semuanya, Allah Swt. Sebagaimana statemen yang sangat terkenal di dunia sufisme, "Ilaahi anta ma'shudi wa ridhaaka mathluubi."

4. Seorang pengusaha muslim seringkali menunjukkan sikap yang bebas, baginya rahmat Tuhan dan rezeki-Nya sangat tak terbatas, sehingga cara dan upaya untuk mencapainya sangat luas pula. Pandangan ini sangat membuat seorang pengusaha muslim menjadi agak tampak merasa terikat dengan sistem yang ada. Namun kebebasannya selalu 
didasarkan pada koridor dan filosofi serta nilai-nilai yang dianggapnya benar terhadap landasan segala usaha dan aktivitasnya.

5. Dengan menangani pekerjaannya, seorang pengusaha muslim sangat memahami proses dan sistem pelaksanaan pekerjaan yang ada pada usahanya. Bahkan dapat menangani kerja yang paling kecil sekalipun dalam proses usaha yang dikembangkannya. Oleh karena itu, ia memiliki kemampuan dalam mendelegasikan wewenang, namun tangkas dalam melakukan pengawasan. Hal ini sejalan dengan praktek Nabi Muhammad Saw yang sangat menguasai filosofi pekerjaan dan sekaligus partikulasinya.

6. Integritas wirausahawan muslim tersebut terlihat dalam sifat-sifatnya sebagai berikut;

- Takwa, tawakal, zikir dan bersyukur

- Motivasinya bersifat vertikal dan horizontal

- Niat suci dan ibadah

- Memandang status dan profesi sebagai amanah

- Aktualisasi diri untuk melayani

- Mengembangkan jiwa bebas merdeka

- Azan bangun lebih pagi

- Selalu berusaha meningkatkan ilmu dan keterampilan

- Suka menyambung tali silaturahim

- Memiliki komitmen pada pemberdayaan

- Menunaikan zakat, infaq, dan sadaqah (ZIS)

- Puasa sunnah

- Shalat sunnah baik siang maupun malam

\section{Saran-saran}

1. Hasil penelitian ini menunjukan bahwa ada korelasi antara variabel-variabel ketaatan beragama dengan kinerja bisnis, untuk kepada selurh pengusaha disarankan untuk:

- Motivasinya bersifat vertikal dan horizontal

- Niat suci dan ibadah

- Takwa, Tawakal, Zikir dan Bersyukur

- Memandang status dan profesi sebagai amanah

- Aktualisasi diri untuk melayani

- Mengembangkan jiwa bebas merdeka

- Azan bangun lebih pagi

- Selalu berusaha meningkatkan ilmu dan keterampilan 
- Suka menyambung tali silaturahim

- Memiliki komitmen pada pemberdayaan

- Menunaikan zakat, infaq, dan sadaqah (ZIS)

- Puasa sunnah

- Shalat sunnah baik siang maupun malam

2. Jumlah sampel dan variabel yang digunakan dalam penelitian ini relatif masih sedikit, sehingga hasil dari penelitian ini belum bisa untuk digeneralisir, untuk itu diperlukan penelitian lanjutan dengan menggunakan sampel yang lebih besar dan variabel yang lebih banyak lagi.

3. Dorongan atau motivasi azas manfaat sebesar-besarnya kepada sesama makhluq Allah swt. Manfaat tidak hanya kepada manusia tetapi terhadap semua kehidupan termasuk lingkungan. Dasar motivasi ini diambil dari makolah "choirun Naas anfauhu lin Naas" yang artinya sebaik-baik manusia adalah yang lebih bermanfaat bagi manusia yang lain. Dari sini memotivasi para pengusaha untuk berlomba lomba berbuat kebaikan dalam kehidupan bersama menjadi lebih semarak.

\section{DAFTAR PUSTAKA}

Arikunto, Suharsimi (1998) Prosedur Penelitian,Suatu Pendekatan Praktek. CetakanKedua. RinekaCipta, Jakarta

AjianuddindalammakalahnyaPengembangan Usaha Kecil danMenengahsebagai Salah SatuUpayaPemulihanPerekonomian Indonesia

Hisrich, R.D. \& Peters, N.P.,1998, Entrepreneurship, Fourth Ed., Irwin/McGraw- Hill. A Division of The McGraw-Hill Co, Missouri.

Hisrich, Robert D., 1991, "Entrepreneurship/Intrapreneurship", in: Staw, Barry M.,Psychological Dimensions of Organizational Behavior, International Ed., Maxwell MacMillan.

Jacobs, H., \& Kruger, S., 2001, Establishing An Intrapreneurial Orientation As Strategy: A Framework For Implementation, ActaCommercii, 1:1-11. 
Abdurrahman Sadikin dan Satira Yusuf

Perren, Lew, 2002, Comparing Entrepreneurship and Leadership: A Textual Analysis,Council for Excellence in Management and Leadership, London.

Riduwan, 2002, SkalaPengukuran Variabel-variabelPenelitian, Alfabeta, Bandung.

Radius Prawiradalambuku "PengembangandanPerlindungan Usaha Kecil" (1980;25)

Riyanti, Benedicta Prihatin Dwi, 2003, Kewirausahaan dari Sudut Pandang Psikologi, Grasindo, Jakarta.

Zimmerer, Thomas W. \& Scarborough, Norman M., 1998, Pengantar Kewirausahaan dan Manajemen Bisnis Kecil, edisi Bahasa Indonesia, Prenhalindo, Jakarta. 